\title{
Probiotic (ROEMIN W2) Improved Growth Performance and Intestinal Histomorphological Structure in Broilers Challenged With E.Coli
}

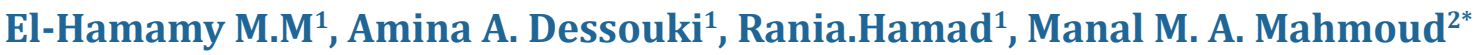 \\ Department of Pathology ${ }^{1}$, Department of Nutrition and Clinical Nutrition ${ }^{2}$, Faculty of veterinary medicine, \\ Suez Canal University, Ismailia, Egypt \\ dr.manalah@gmail.com
}

\begin{abstract}
Thecurrent study investigated the role of commercialprobiotic(ROEMIN W2)on growth performance and in preventing or treating chicks challenged with E.coli.Three hundred one day- old mixed Cobb broiler chicks, divided into 5 groups and reared for 42 days. G1was the control group. G2 received probiotic (ROEMIN W2). G3challenged with E.coli. G4challenged with E.coli after receiving of ROEMIN W2. G5challengedfirstly with E.coli then received ROEMIN W2. Body weight gain, feed consumption, and feed conversion ratio calculated for the complete experimental period. Two birds from each replicate were taken and slaughtered (at the $3^{\text {rd }}$ and $6^{\text {th }}$ weeks) for determination of carcass weight. Duodenum collected for both histomorphological and scanning electron microscope studies.ROEMIN W2 significantly improved performance in G2andG4 in spite of the E. coli infection compared to control group. G5 had the same FCR and carcass weight as the control group in spite of the E. coli infection. There was a significantly decreased growth performance in the E coli infected non ROEMIN W2 supplemented group, G3 compared to all other treatments. The collected data revealed pronounced intestinal villi improvement in groups treated with probiotic,while infected non- treated group showed decrease length of villi and increase depth of the crypts recorded. Scanning Electron microscope of groups treated with probiotics showed normal length long finger-like projection.Crypt area showed a numerous number of proliferating enterocytes having longer microvilli. Whereas the E. coli infected group showed short distorted duodenal villi with massive destruction and loss.
\end{abstract}

Keywords: Intestine histomorphology,lactic acid bacteria, broilers, growth performance, E.Coli.

\section{INTRODUCTION}

In modern intensive poultry production, normal flora is slow in colonizing the intestine of newly hatched chicks(Fuller, 1989).Therefore,antibiotics are usedto prevent diseases and improve growth performance. The use of antibiotics in poultry industry led to development of drug-resistant bacteria (Sorum and Sunde, 2001), drug residues in the body of the birds (Burgat, 1999), and imbalance of normal flora (Andremont, 2000).All of the above led to banning of antibiotic use in poultry diets. One alternative of antibiotics is the use of probiotics.

Probiotics are live microorganisms which, when administered in adequate amount, confer a health benefit on the host (FAO/WHO, 2002) and have beneficial effects on growth performance (Dizaji et al., 2012). Efforts made to develop commercial probiotics in which organisms such as Lactobacillus and Bifidobacterium species are incorporated. These commercial probiotics may modulate gut microbial composition, leading to improved gut health and improved resistance to pathogenic bacteria (Staton et al., 2001).

The objective of the current study was to observe the role of water-solubleprobiotic(ROEMIN W2)on growth performance and in preventing or treating chicks infected with E.coli. 


\section{Material AND Methods}

\section{Experimental Design}

Three hundred one day- old, mixed Cobb broiler chicks were used. Chicks were randomly distributed into five groups. Each group had three replicates 20 birds each. Birds reared for 42 days. The first group G1 is the control non-treated non-challenged group. In G2, birds were given the commercial probiotic ROEMIN W2( each g contains Lactobacillus acidophilus 2x108 CFU, Lactobacillus thermophilus 2x108 CFU, Bifidobacterium 1 $\mathrm{x} 108 \mathrm{CFU}$ and Lactose) (China way corporation, Taiwan) at dose of $0.5 \mathrm{~g}$ per 1 liter of drinking water daily for 6weeks. G3 wasnon-probiotic treated only challenged with E-coli at $7^{\text {th }}$ day. G4 given ROEMIN W2 from the first day to the $7^{\text {th }}$ day $(0.5 \mathrm{~g} /$ liter $)$ then challenged with E. coli. G5 challengedwith E. coli at $7^{\text {th }}$ day then given ROEMIN W2 after appearance of symptoms of infection for seven days, with double the recommended dose, $1 \mathrm{~g}$ per 1 liter. Birds housed in floor pens, maintained under continuous lightening program, good ventilation, suitable temperature (begin at $32^{\circ} \mathrm{C}$ and decreased one ${ }^{\circ} \mathrm{C}$ every two days until $26{ }^{\circ} \mathrm{C}$ ). Birds had free access to feed and water. Experimental diets formulated according to NRC (1994) Table (1). Birds were vaccinated at the 5th day by Hitchner B1 eye drops (intervet:Holland) for Newcastle disease. Gumboro eye drops vaccine used at $14^{\text {th }}$ and $28^{\text {th }}$ days (BURSA-VAC $®$ Millsboro, Delaware, U.S.A). Lasota was used at $21^{\text {st }}$ and $31^{\text {st }}$ days of age (intervet:Holland) for Newcastle disease. E. coli challenge applied according to Awaad (1972). Birds were inoculated with $0.6 \mathrm{ml}$ saline suspension containing 2x107 C.F.U E. coli strain 078:K80 intra-crop at 7 day old ( the bacteria was kindly obtained from Ismailia, animal health research institute).

Table 1. The composition of the experimental diets.

\begin{tabular}{|l|c|c|}
\hline \multicolumn{1}{|c|}{ Ingredients } & $\begin{array}{c}\text { Starter } \\
\text { (0-3weeks) }\end{array}$ & $\begin{array}{c}\text { Grower-Finisher } \\
\text { (4-6 weeks) }\end{array}$ \\
\hline Ground yellow corn & 56.7 & 66.6 \\
\hline Soya bean meal (44\% CP) & 29.5 & 23.53 \\
\hline Fish meal (60.5\% CP) & 7.0 & 5.0 \\
\hline Soya bean oil & 4.06 & 2.02 \\
\hline Dicalcium phosphate & 0.88 & 0.6 \\
\hline Limestone & 1.26 & 0.69 \\
\hline DL - Methionine (purity 96\%) & 0.1 & 0.25 \\
\hline Iodized sodium chloride & 0.25 & 0.25 \\
\hline Vitamins \&mineral premix* & 0.25 & 19.0 \\
\hline \multicolumn{1}{|c|}{ Calculated composition } & 22.0 & 3040.0 \\
\hline Crude protein & 3060.0 & 160.0 \\
\hline ME kcal per kg & 139.0 & \multicolumn{2}{|c|}{} \\
\hline Calorie/protein ratio(C/P) & \multicolumn{2}{|c|}{} \\
\hline
\end{tabular}

* Each $2.5 \mathrm{~kg}$ contain the following vitamins and minerals:

Vit. A 12 mIU, vit. $D_{3} 2$ mIU, vit. E $1000 \mathrm{mg}$, vit. $\mathrm{k}_{3} 2000 \mathrm{mg}$, vit. $B_{1} 1000 \mathrm{mg}$, vit. $B_{2} 5000 \mathrm{mg}$, vit. $B_{6} 1600 \mathrm{mg}$, vit. $B_{12}$ $10 \mathrm{mg}$, biotin $50 \mathrm{mg}$, pantothinic acid $10000 \mathrm{mg}$, nicotinic acid $30000 \mathrm{mg}$, folic acid $1000 \mathrm{mg}$, manganese $6000 \mathrm{mg}$, zinc $5000 \mathrm{mg}$, iron $3000 \mathrm{mg}$, copper $10000 \mathrm{mg}$, iodine $1000 \mathrm{mg}$, selenium $100 \mathrm{mg}$, cobalt $100 \mathrm{mg}$, carrier $\left(\mathrm{CaCO}_{3}\right)$ to $2.5 \mathrm{~kg}$. (AGRI-VET. Under technical assistance of HELM Germany) 


\section{Evaluation of Growth Performance}

Diets offered ad libitum. Water, either supplemented with ROEMIN W2 or not was constantly available. Residual feed collected daily.Body weight was determined weekly on individual basis. Body weight gain, feed consumption and feed conversion ratio (FCR, Feed: Gain)were calculated. The overall Body weight gain, feed consumption, and FCR calculated for the complete experimental period (Brady, 1968).

Two birds from each replicate were taken and slaughtered (at the $3^{\text {rd }}$ and $6^{\text {th }}$ weeks) for determination of carcass weight. Their feather plucked, and their head and feet (shank) cut off.

\section{Histopathological Examination}

Specimens from duodenum were collected in 10\% buffered formalin for histopathological examination according to (Bancroft et al., 1990).Samples used to evaluate the following parameters: villus height and crypt depth.Quantitative morphometric estimations done using image analyzer (Leica imaging system. Ltd, Cambridge, England).

\section{Scanning Electron Microscope (SEM)}

Small pieces $2-3 \mathrm{~mm}^{2}$ of the duodenum quickly excised washed in normal saline, fixed in $3 \%$ glutaraldehyde for 24 hours at $4^{\circ} \mathrm{C}$. Then, the specimens washed in sodium cacodylate buffer $(0.1 \%$ molarity, pH 7.2$) 3-4$ times for four hours and post fixation in $1 \%$ osmium tetroxide for 24 hoursthen rinsed three times in distilled water. The specimens dehydrated through a graded ascending ethanol series (from 10 to 100\%) (30 min each), dried with liquid $\mathrm{CO}_{2}$. The specimens mounted on stubs with double sided adhesive taps coated with gold Bancroft et al. (1990). Then examined by a scanning electron microscope (JEOL JXA-84OA ELECTRON PROBE MICROANALYZER).In the electron Microscope Unit, of the National center for research, EL Douki, Cairo, Egypt.

\section{Statistical Analysis}

Data collected analyzed to compare means, using a statistical software program (SPSS for windows, version 14, USA). Differences among means of different groups carried out using one-way ANOVA with Duncan multiple comparison test.

\section{RESULTS}

\section{Growth Performance Parameters}

ROEMIN W2 significantly increased final body weight, weight gain, feed consumption and carcass weight in G2 (probiotics only) compared to control group (G1)(Table 2). ROEMIN W2 significantly increased final body weight, weight gain, improved FCR and carcass weight in G4 in spite of the E. coli infection compared to control group, G1. G5 had the same FCR and carcass weight as the control group in spite of the E. coli infection. There was a significantly decreased growth performance in the E coli infected non ROEMIN W2 supplemented group, G3 compared to the control and all other treatments.

Table 2. Effect of different experimental treatments on growth performance (Mean \pm SE)*

\begin{tabular}{|l|l|l|l|l|l|}
\hline \multicolumn{1}{|c|}{ Parameters } & \multicolumn{1}{c|}{ G1 } & \multicolumn{1}{c|}{ G2 } & \multicolumn{1}{c|}{ G3 } & \multicolumn{1}{c|}{ G4 } & \multicolumn{1}{c|}{ G5 } \\
\hline Initial body weight, g/bird & $46.09 \pm 0.58$ & $45.42 \pm 0.55$ & $46.36 \pm 0.60$ & $46.39 \pm 0.72$ & $46.36 \pm 0.64$ \\
\hline Final body weight, $\mathrm{kg} / \mathrm{bird}$ & $2.10 \pm 14.76^{\mathrm{c}}$ & $2.27 \pm 4.38^{\mathrm{a}}$ & $1.80 \pm 13.22^{\mathrm{e}}$ & $2.15 \pm 12.83^{\mathrm{b}}$ & $2.02 \pm 8.82^{\mathrm{d}}$ \\
\hline Body weight gain, $\mathrm{kg} /$ bird & $2.05 \pm 14.21^{\mathrm{c}}$ & $2.23 \pm 11.90^{\mathrm{a}}$ & $1.80 \pm 6.55^{\mathrm{e}}$ & $2.10 \pm 4.47^{\mathrm{b}}$ & $1.96 \pm 14.47^{\mathrm{d}}$ \\
\hline Feed consumption, $\mathrm{kg} /$ bird & $3.57 \pm 30.50^{\mathrm{c}}$ & $3.90 \pm 15.04^{\mathrm{a}}$ & $3.66 \pm 30.73^{\mathrm{b}}$ & $3.53 \pm 34.75^{\mathrm{c}}$ & $3.37 \pm 23.72^{\mathrm{d}}$ \\
\hline FCR & $1.74 \pm 0.03^{\mathrm{b}}$ & $1.74 \pm 0.01^{\mathrm{b}}$ & $2.03 \pm 0.01^{\mathrm{a}}$ & $1.68 \pm 0.02^{\mathrm{c}}$ & $1.72 \pm 0.01^{\mathrm{bc}}$ \\
\hline Carcass weight, $\mathrm{kg} /$ bird & $1.66 \pm 9.03^{\mathrm{c}}$ & $1.88 \pm 6.16^{\mathrm{a}}$ & $1.57 \pm 29.04^{\mathrm{d}}$ & $1.72 \pm 17.35^{\mathrm{b}}$ & $1.61 \pm 8.56^{\mathrm{c}}$ \\
\hline
\end{tabular}

*Means with the different letters $(a, b, c . .$.$) in the same raw are significantly different p \leq 0.05$. 


\section{Histomorphological Measurements}

\section{Length of intestinal villi}

ROEMIN W2improved villi length in G2 (probiotic only) at $3^{\text {rd }}$ week anda significant increase in villi length was seen in G2at $6^{\text {th }}$ week compared with allother groups(Table 3, Chart 1).G4, showed a significant increase in length of villi at $3^{\text {rd }}$ and $6^{\text {th }}$ weeks. ROEMIN W2supplementation kept the villi length in G5 as the control group after E coli infection, whileG3 (infected non-treated group), showed significant decrease in length of villi at $3^{\text {rd }}$ and $6^{\text {th }}$ weeks when compared with other groups.

Table 3. Effect of different experimental treatments on length of intestinal villi (Mean \pm SE)

\begin{tabular}{|l|l|l|l|l|l|}
\hline \multicolumn{1}{|c|}{ Trime } & G1 & G2 & G3 & G4 & G5 \\
\hline $3^{\text {rd }}$ week & $1076^{\mathrm{C}} \pm 47$ & $1137^{\mathrm{C}} \pm 19$ & $838.5^{\mathrm{D}} \pm 40$ & $1546^{\mathrm{A}} \pm 22$ & $1364^{\mathrm{B}} \pm 37$ \\
\hline $6^{\text {th }}$ week & $1118.7^{\mathrm{C}} \pm 38$ & $2013^{\mathrm{A}} \pm 43$ & $851.5^{\mathrm{D}} \pm 34$ & $1515^{\mathrm{B}} \pm 16$ & $1137^{\mathrm{C}} \pm 56$ \\
\hline
\end{tabular}

Mean within the same raw having different letters (A, B, C...) are highly significant different at $\mathrm{p} \leq 0.001$

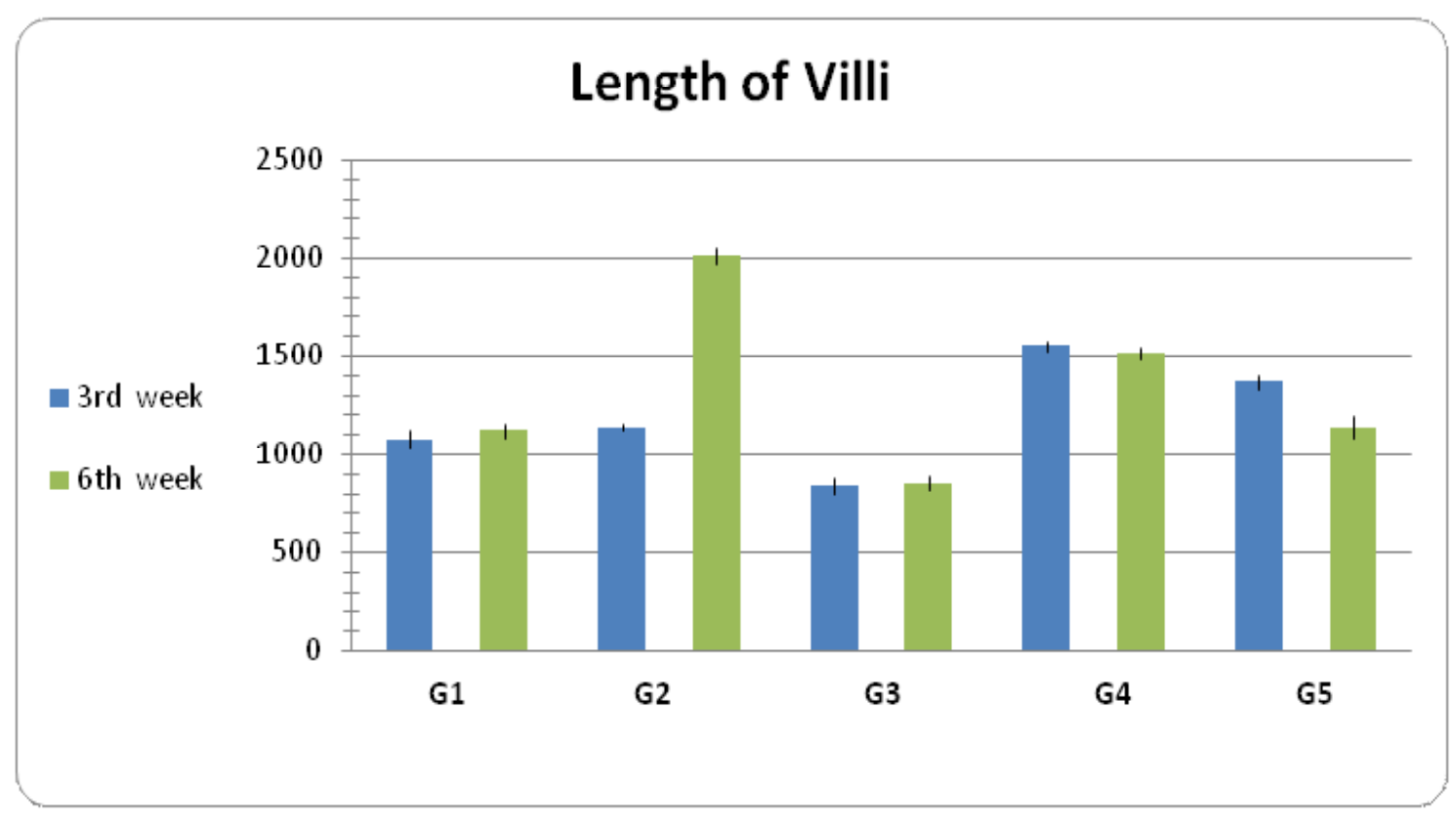

Chart 1. Effect of different experimental treatments on length of intestinal villi

\section{Depth of crypt}

G1, at $3^{\text {rd }}$ week showed significant increase in depth of crypt when compared with other groups.At $6^{\text {th }}$ week, showed significant decrease when compared with other groups(Table 4, Chart 2). G3, at $6^{\text {th }}$ week showed a significant decrease in depth of crypt when compared with control group and Probiotics only.G4, at $6^{\text {th }}$ week, showed a significant decrease in depth of crypt when compared with other groups.G5at $6^{\text {th }}$ weeks, showed a significant increase in depth of crypt when compared with other groups. 
Table 4. Effect of different experimental treatments on depth of intestinal crypt(Mean \pm SE)

\begin{tabular}{|l|l|l|l|l|l|}
\hline $\begin{array}{l}\text { Troup } \\
\text { Time }\end{array}$ & G1 & G2 & G3 & G4 & G5 \\
\hline $3^{\text {rd }}$ week & $206^{\mathrm{b}} \pm 15$ & $271^{\mathrm{a}} \pm 10$ & $235^{\mathrm{ab}} \pm 22$ & $218^{\mathrm{b}} \pm 18$ & $222^{\mathrm{b}} \pm 17$ \\
\hline $6^{\text {th }}$ week & $182^{\mathrm{c}} \pm 13$ & $137^{\mathrm{d}} \pm 10$ & $276^{\mathrm{a}} \pm 15$ & $224^{\mathrm{b}} \pm 10.5$ & $257^{\mathrm{a}} \pm 20$ \\
\hline
\end{tabular}

Means within the same raw having different letters $(a, b, c . .$.$) are significant different at p \leq 0.05$

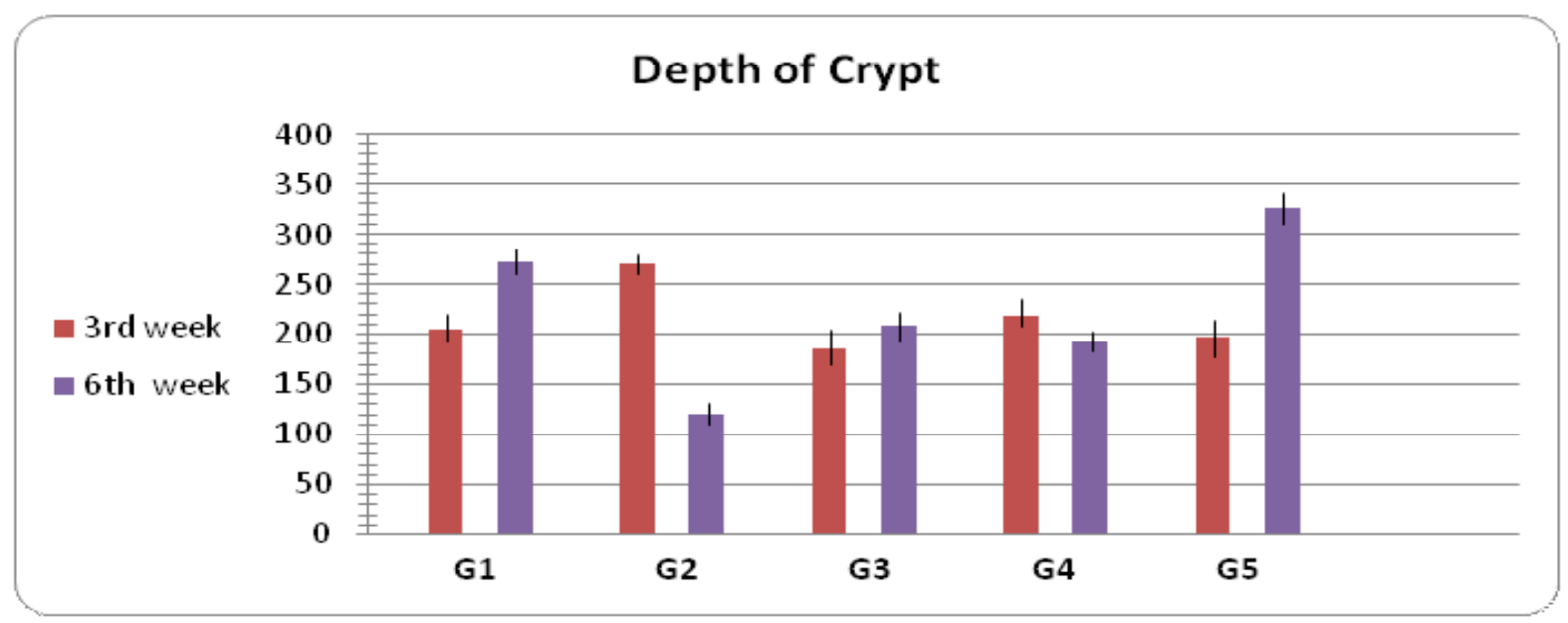

Chart 2. Effect of different experimental treatments on depth of intestinal crypt

\section{Small intestine}

G1the control group showed normal long intestinal villi with normal linningepith. ( Fig 1- A). G2 that fed probiotics only showed normal healthy long intestinal villi (Fig1-B). G3 (infected non-treated group) showed severe destruction, necrosis, desquamation, fusion and shortening of duodenal villi (Fig1-C). G4 showed normal histological architecture, including long villi with normal epithelial lining and normal intestinal glands (Fig1-D). G5 (infected supplemented group) showed mild to moderate destruction, shortening of intestinal villi and hyperplasia of glands (Fig1-E).

\section{Scanning Electron Microscope}

Reveled the beneficial effect ofROEMIN W2 supplementation. The shape of duodenal villi of control group (G1) showed the normal finger tongue-like projections. Each villus has a wide base triangular on side and has curled tips (Fig 2-a). The lateral side appearance of the villi showed the epithelial cells activity represented by dome -shaped cells with protuberances and epithelial crevice (Fig 2-f). The crypt area showed numerous numbers of proliferating enterocytes with characteristic arrangement as long columnar cells and having long microvilli (Fig 3-a).In G2, the duodenal villi showed normal lengthily long finger-like projection (Fig 2-b). The epithelial cells revealed the normal healthy appearance, dome shaped with longer microvilli and shortening of the depth of crypt area. The crypt area showed a numerous number of proliferating enterocytes that having longer microvilli than that of the control group (Fig 3-b).G3, Showed shortening of intestinal duodenal villi with rough and distorted surface. Massive destruction and loss of several villi were also observed (Fig 2-c) The Intestinal mucosa and epithelial cells of some villi as well as those in crypt areas showed massive necrosis, porous and collapsed villi tips with several blebs (Fig 3-c).G4, the intestinal villi showed normal lengthy villi (Fig 2-d), crypt area and cells in both villus surfaces was healthy and normal (Fig 3-d). G5, the Intestinal villi and its mucosa showed mild, moderate destruction of the microvilli structure (Fig 2-e). Mild to moderate necrosis and adhesion of epithelial cells with loss of their microvilli. (Fig 3-e). 

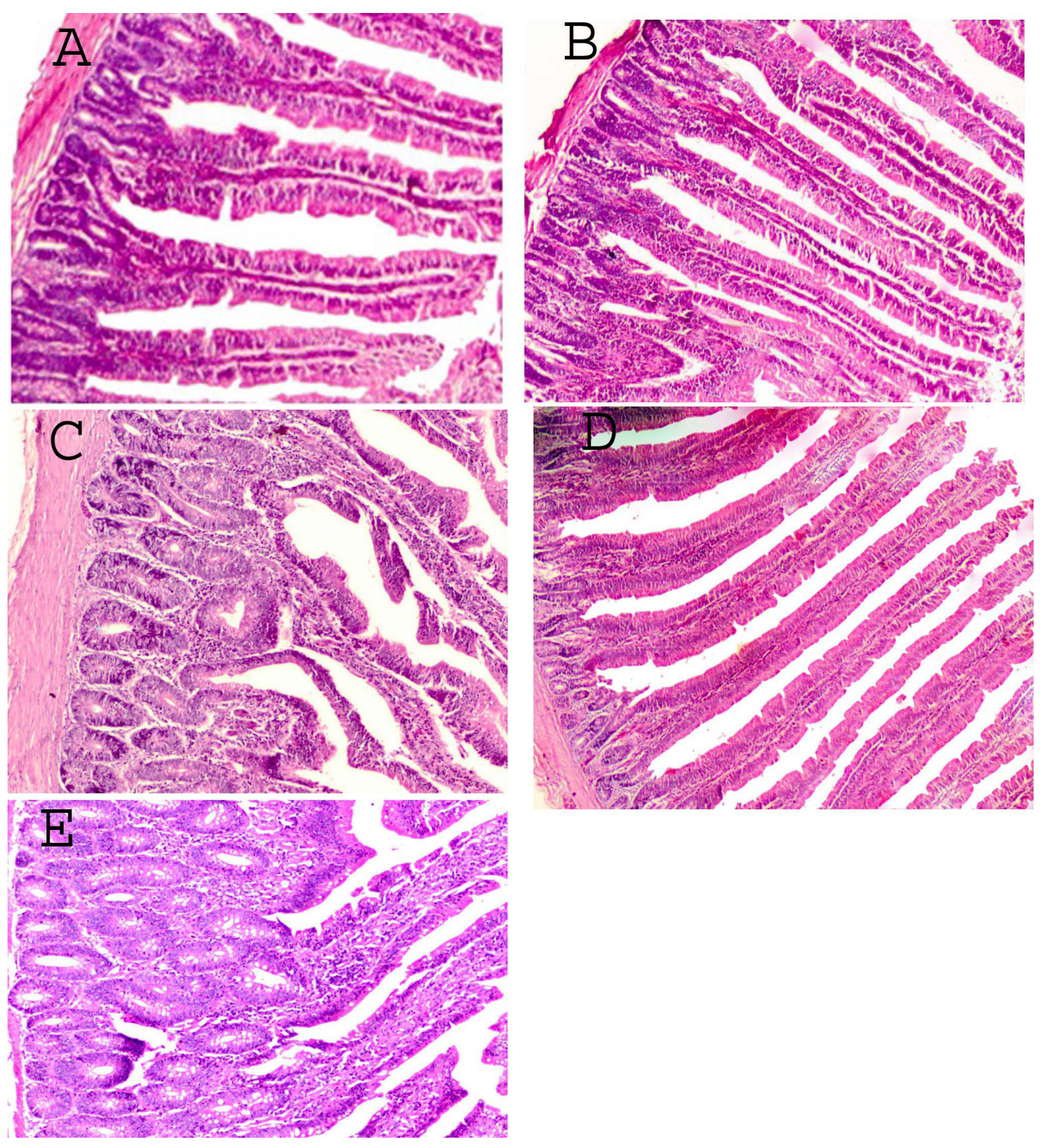

Fig1. Duodenum, $H \& E(A) \&(B): G 1$ and $G 2,6 r d$ week, showing normal histological integrity of epithelial cell lining the villi. X4. (C): G3, 6th -week showing necrosis, sloughing and desquamation of epithelium, mononuclear cell infiltration, shortening, fusion and atrophy of vill.iX 10. (D): duodenum, G4, 6th week showingnormal histological architecture, including long villi with normal epithelial lining and normal intestinal glands.X10. (E): duodenum, G5, 6th week showing hyperplasia of intestinal glands, mild atrophy and shortening of villi. X4. 

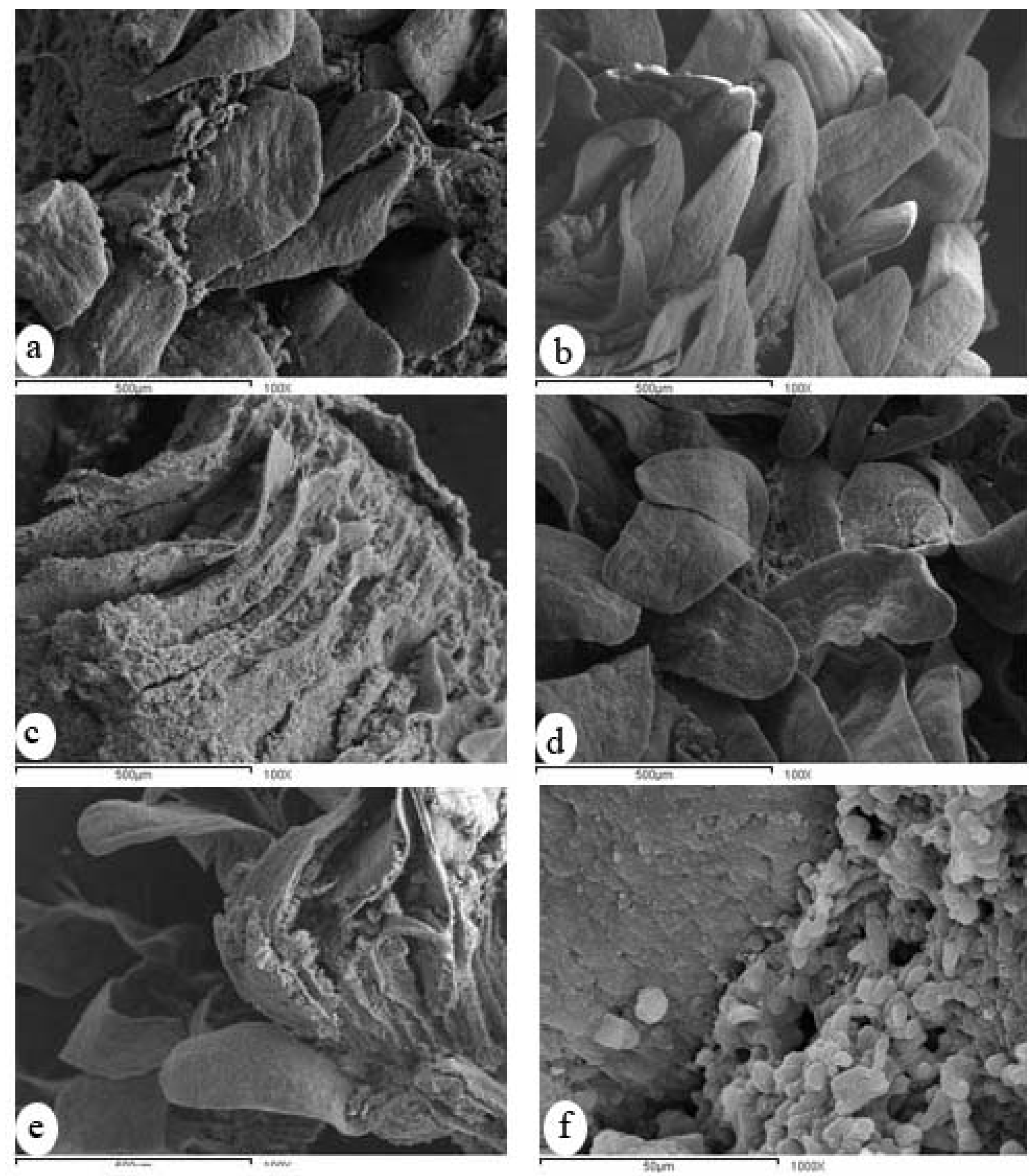

Fig2. Scanning electron micrograph of duodenum showing normal healthy architecture of duodenal villi with smooth surface ( $a, G 2)$. More healthy lengthy villi (b, G2 LAB). Shortening of intestinal duodenal villi with rough and distorted surface (c, G3). Normal villi length and surface (d, G4). Mild to moderate destruction (e, G5). X 100, Scale bar, $500 \mu \mathrm{m}$. Side appearance of villi (f, G1).X 1000. Scale bar, $50 \mu \mathrm{m}$ 

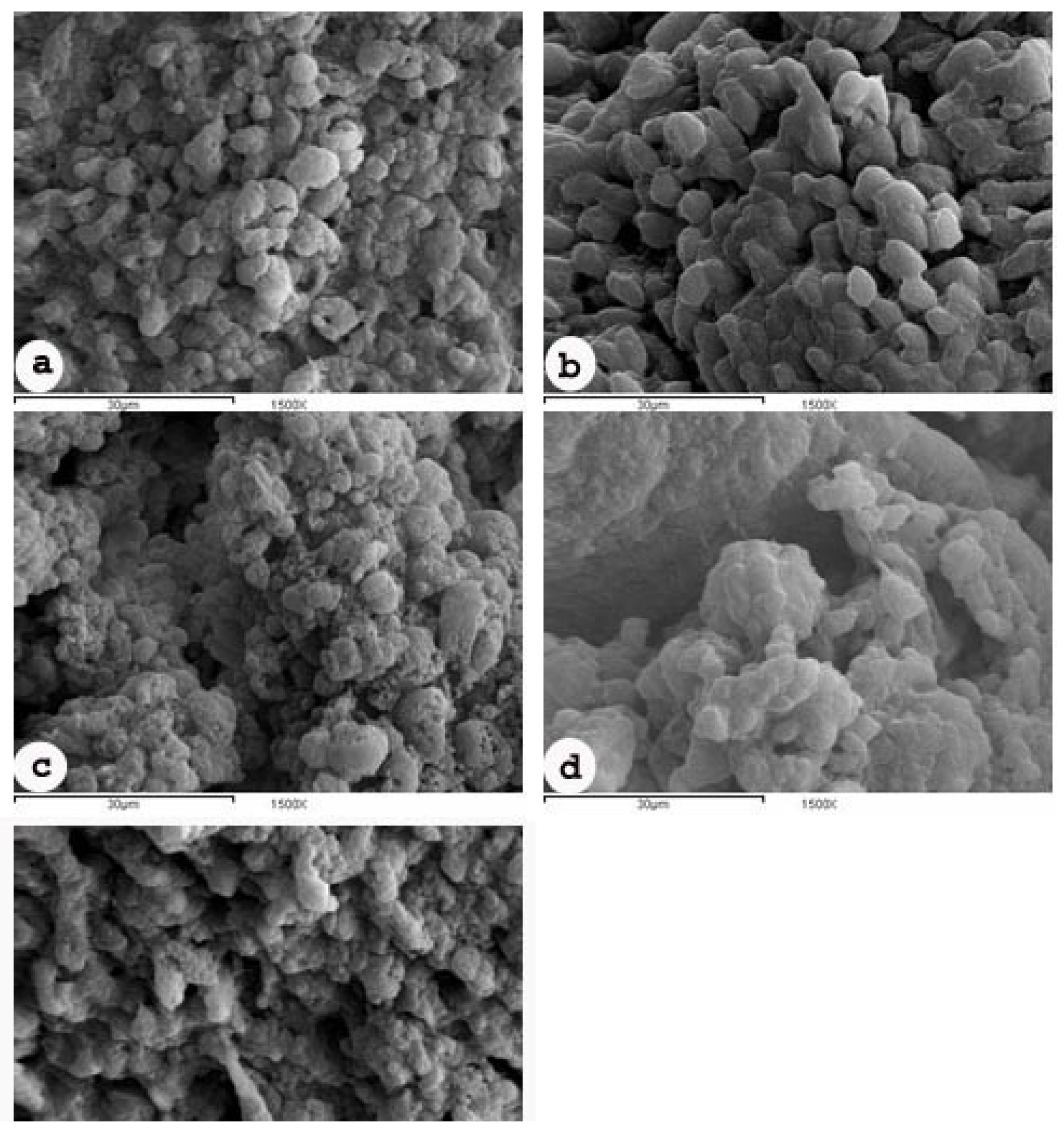

Fig3. Scanning electron micrograph of duodenum crypt area showing numerous numbers of proliferating enterocytes having long microvilli (a, G1). More healthy longer cells with taller microvilli $(b, G 2)$. Massive necrosis, adhesion, porous and collapse of epithelial cells with loss of microvilli (c, G3). Normal epithelial cells with long microvilli $(d, G 4)$. Mild to moderate necrosis and adhesion of epithelial cells with destruction of their microvilli (e, G5). X 1500, Scale bar, $10 \mu \mathrm{m}$. 


\section{DiscusSiON}

The significant improvement in growth performance in the present study is in agreement with previous research done to evaluate the effects of lactobacillus-based probiotic on broiler chicken (Gibson and Fuller, 2000; Zulkifli et al., 2000; Midilli and Tuncer, 2001; Kabir et al., 2004; Mountzouris et al., 2007; Samli et al., 2007; and Hamed Kioumarsi et al., 2012).This improvement is thought to be related to different modes of action, including:(1) maintaining normal intestinal microflora by competitive exclusion and antagonism (Kabiret al., 2005; Kizerwetter-Swida,and Binek, 2009). Probiotic supplementation allowed the rapid establishment of beneficial bacteria in the digestive tract of the bird. Therefore, improved intestinal environment and increased efficiency of digestion and absorption of nutrients (Edens, 2003).(2) Altering metabolism, improving feed intake and digestion by increasing digestive enzyme activity and decreasing bacterial enzyme activity and ammonia production (Nahanshon et al., 1992; Nahanshon et al., 1993; Dierck1989; Yoon et al., 2004;Awadet al., 2006). Lactobacillus-based probiotic deliver many lactic acid bacteria into the gastrointestinal tract, that modifies the intestinal milieu and deliver enzymes and other beneficial substances into the intestines (Marteau and Rambaud 1993). Supplementation significantly increased the levels of amylase after 40 days of feeding (Jin et al., 2000). Also, L. acidophilus supplementation to chicken increased microvilli height leading to enlargement of the microvilli absorptive surface and enabling optimal utilization of nutrients (Ezema, 2013). (3) Stimulating the immune system (Kabir et al., 2004; Nayebpor et al., 2007; Apata 2008; Brisbin et al., 2008).

In spite of E. coli infection ROEMIN W2 addition lead to an improved performance in G4 and maintained a similar FCR and carcass weight in G5 compared to the control,suggesting an improved intestinal balance of microbial population in probiotic treatments. The addition of probiotic promoted the growth of beneficial bacteria and so provided a healthier intestinal system for better absorption of nutrients (Kelly et al., 1994; Rada and Rychly, 1995; Line et al., 1998; Salminen etal., 1998; and Pascual etal., 1999). While G3 (the non-probiotic supplemented, E coli infected) remained the group with lowest performance. E coli as a pathogen caused disturbances in the normal flora or in the intestinal epithelium that altered the permeability of this natural barrier, facilitating the invasion of pathogens and detrimental substances, modifying the metabolism, the ability to digest and absorb nutrients, and leading to chronic inflammatory processes at the intestinal mucosa (Hofstad, 1972; Podolsky, 1993; Oliveira, 1998). As a result, there was a decrease in the villus, increase in the cell turnover and decrease in the digestive and absorptive activities (Visek, 1978).ROEMIN W2 use counteracted this effect as seen in G4and G5.Probiotics may produce antimicrobial substances and organic acids that protect the villi and absorptive surfaces against toxins produced by pathogens, as well as stimulate the immune system (Ewing and Cole, 1994; Walker and Duff, 1998; Pelicano et al., 2002).

\section{CONCLUSION}

ROEMIN W2 supplementation significantly improved growth performance in broilers. Also displayed a growthpromoting effect in spite of the E. coli infection. This product offers a good antibiotic alternative to improve poultry production. It is our recommendation touse it in commercial farms.

\section{REFERENCES}

Andremont, A. (2000).Consequences of antibiotic therapy to the intestinal ecosystem. Ann. Fr. Anesth. Reanim. 19: 395-402.

Apata, D.F. (2008). Growth performance, nutrient digestibility and immune response of broiler chicks fed diets supplemented with a culture of Lactobacillus bulgaricus. J. Sci. Food Agric. 88: 1253-1258.

Awaad, M. (1972): Studies on E-coli infection in chicken .M.V.SC thesis (Poult.Dis) Cairo Univ.Fac.Vet.Med. 
Awad, W.A.; Bohm, J.; Razzazi-Fazeli, E.; Ghareeb, K.; Zentek, J.(2006): Effect of addition of a probiotic microorganism to broiler diets contaminated with deoxynivalenol on performance and histological alterations of intestinal villi of broiler chickens. Poult. Sci. 85: 974-979.

Bancroft, J.P; Stevenes, A. and Turner, D.R. (1990). Theory and Practice of Histological Techniques, 3rd ed. Clurechill Livingston, Edinburgh, London.

Brady,W.L. (1968). Measurments of some poultry performance parameters .Vet.Res. 88:245-260.

Brisbin, J.T.; Zhou, H.; Gong, J.; Sabour, P.; Akbari, M.R.; Haghighi, H.R.; Yu, H.;

Burgat, V. (1999). Influence of different levels of humic acid and esterified glucomannan on growth performance and intestinal morphology of broiler chickens. Rev. Prat. 41: 985-990.

Dierck, N.A.(1989): Biotechnology aids to improve feed and feed digestion: Enzymes and fermentation. Arch. Anim.Nutr. Berl. 39: 241-261.

Dizaji, B.R.; Sajjad Hejazi and Zakeri,A. (2012). Effects of dietary supplementations of prebiotics, probiotics, synbiotics and acidifiers on growth performance and organs weights of broiler chicken. Euro. J. Exp. Bio. 2 (6):2125-2129.

Edens, F.W. (2003). An alternative for antibioticuse in poultry probiotics. Brazilian Journal of Poultry Sciences. 5: 75-97.

Ewing, W.N. and Cole, D.J.A. (1994). the living gut: An introduction to microorganisms in nutrition. Dungannon, UK: Context Publication; 220 p.

Ezema, C. (2013): Probiotics in animal production: A review. Journal of Veterinary Medicine and Animal Health. 5:308-316. DOI: 10.5897/JVMAH2013.0201.

FAO/WHO, (2002). Probiotice in food health nutritional properties and guidelines for evaluation. Joint FAO/ WHO (Food and Agriculture Organization/ World Health Organization) Joint working group report on drafting guidelines for evaluation of probiotics in food. London, Ontario, Canada. 30 April- 1 May 2002, $1-11$.

Fuller, R. (1989).Probiotics in man and animals. J. Appl. Microbiol. 66 (5): 365-378.

Gibson, G.R. and Fuller, R. (2000). Aspects of in vitro and in vivo research approaches directed toward identifying probiotics and prepiotics for human use. J. Nutr. 130: 391-395.

Hamed Kioumarsi, Roozbeh Shabani, Mehran Nosrati, Faramin Javandel, and Ali Ahmad Alaw Gothbi (2012). The effect of probiotics on growth performance of broilers.Annals of Biological Research, 3 (12):5450-5452.

Hofstad, M.S. editor. (1972). Diseases of poultry. 6th ed. Ames: The Iowa State University Press; 1972. $1176 \mathrm{p}$.

Jin, L.Z.; Ho, Y.W.; Abdullah, N.; Jalaludin, S. (2000): Digestive and bacterial enzyme activities in broilers fed diets supplemented with Lactobacillus Cultures. Poult. Sci. 79: 886-891.

Kabir, S. M. L.; Rahman, M. M.; Rahman, M. B.; Rahman, M. M.; and Ahmed S.U. (2004): The dynamics of probiotics on growth performance and immune response in broilers. Int. J. Poult. Sci. 3:361-364.

Kabir, S.M.L.; Rahman, M.M.; Rahman, M.B.; Hosain, M.Z.; Akand, M.S.I.; Das, S.K. (2005): Viability of probiotics in balancing intestinal flora and effecting histological changes of crop and caecal tissues of broilers. Biotechnology 4: 325-330. 
Kelly, D.; Begbie, R.; and King, T.P. (1994):Nutritional influences on interactions between bacteria and the small intestinal mucosa. Nutr. Rse. Rev. 7:233-257.

Kizerwetter-Swida, M.; Binek, M. (2009): Protective effect of potentially probiotic Lactobacillus strain on infection with pathogenic bacteria in chickens. Pol. J. Vet. Sci. 12: 15-20.

Line, J.E.; Bailey, J.S.; Cox, N.A.; Stern, N.J.; and Tompkins, T. (1998): Effect of yeast-supplemented feed on Salmonella and Campylobacter populations in broilers. Poult. Sci. 77:405-410.

Marteau, P.; Rambaud, J.C.( 1993): Potential of using lactic acid bacteria for therapy and

immunomodulation in man. FEMS Microbiol. Rev. 12: 207-220.

Midilli, M. and Tuncer, S. D. (2001). The effects of enzyme and probiotics supplementation to diets on broiler performance. Turk J. Anim. Sci. 25, 895-903.

Mountzouris, K.C.; Tsistsikos, P.; Kalamara, E.; Nitsh, S.; Schatzmayr, G.; and Fegeros, K. (2007): Evaluation of the efficacy of a probiotic containing Lactobacillus, Bifidobacterium, Enterococcus, and Pediococcus strains in promoting broiler performance and modulating cecal microflora composition and metabolic activities. Poult. Sci. 86:309-317.

Nahanshon, S.N.; Nakaue, H.S.; and Mirosh, L.W. (1992): Effects of direct fed microbials on nutrient retention and parameters of laying pullets [abstract]. Poultry Science 71(Suppl 1):111.

Nahanshon, S.N.; Nakaue, H.S.; and Mirosh, L.W. (1993): Effects of direct fed microbials on nutrient retention and parameters of Single White Leghorn pullets. Poultry Science. 72(Suppl 2):87.

Nayebpor, M.; Farhomand, P.; Hashemi, A. (2007): Effects of different levels of direct fed microbial (Primalac) on growth performance and humoral immune response in broiler chickens. J. Anim. Vet. Adv. 6: 1308-1313.

NRC, (1994): Nutrient Requirements of Poultry. (9th rev. Ed.). National Research Council. National Academy Press. Washington, D.C., USA.

Oliveira, P.B. (1998). Influência de fatores antinutricionais de alguns alimentos sobre o epitélio intestinal e o desempenho de frangos de corte [Dissertação]. Maringá: Universidade Estadual de Maringá.

Pascual, M.; Hugas, M.; Badiola, J.I.; Monfort, J.M.; and Garriga, M. (1999): Lactobacillus salivaricus CTC 2197 prevents Salmonella enteritidis colonization in chicken. Appl. Environ. Micorbiol. 65: 4981-4986.

Pelicano, E.R.L.; Souza, P.A.; Souza, H.B.A. (2002). Prebióticos e Probióticos na nutrição de aves. Ciências Agrárias e da Saúde. 2(1):59-64.

Podolsky, D.K. (1993). Regulation of intestinal epithelial proliferation: a few answers, many questions. Animal Journal Physiologic 264, p: G179-G186.

Rada, V.; and Rychlý, I. (1995): The effect of Lactobacillus salivarius administration on coliform bacteria and enterococci in the crop and cecum of broiler chickens. Vet. Med (Praha) 40:311-315.

Salminen, S.; Bouley, C.; Boutron-Ruault, M.C.; Cummings, J.H.; Franck ,A.; Gibson, G.R.; Isolauri, E.; Moreau, M.C.; Roberfroid, M.; and Rowland, I. (1998): Functional food science and gastrointestinal physiology and function. Br. J. Nutr. 80(Suppl 1):S147-171.

Samli, H.E.; Senkoylu, N.; Ko,c.; F, Kanter, M.; and Agma, A.( 2007): Effects of Enterococcus faecium and dried whey on broiler performance, gut histomorphology and microbiota. Archives of Animal Nutrition $.61: 42-49$. 
Stanton, C.; Gillian Gardiner; Hillary Meehan; Collins, K.; Fitzgerald,G.; Brendan, P.; Lynch, and Paul Ross. (2001). Market potential for probiotics. Am J Clin Nutr, 73(suppl):476S-83S.

Sorum, H. and M. Sunde, (2001).Resistance to antibiotics in the normal flora of animals. Vet. Res. 32: 227241.

Visek, W. J. (1978). The mode of Growth Promotion by Antibiotics. Journal of Animal Science. 46:1447-1469.

Walker, W. A.; and Duff, L.C. (1998). Diet and bacterial colonization: Role of probiotics and prebiotics. Journal Nutrition Biochemical. 9:668-675.

Yoon, C.; Na, C.S.; Park, J.H.; Han, S.K.; Nam, Y.M.; Kwon, J.T.(2004): Effect of feeding multiple probiotics on performance and fecal noxious gas emission in broiler chicks. Kor. J. Poult. Sci 3: 229-235.

Zulkifli, I.; Abdullah, N.; Azrin, N. M.; and Ho, Y.W. (2000): Growth performance and immune response of two commercial broiler strains fed diets containing Lactobacillus cultures and oxytetracycline under heat stress conditions. Br. Poult. Sci.41: 593-597.

Citation: El-Hamamy M.M, Amina A. Dessouki, Rania.Hamad, Manal M. A. Mahmoud, "Probiotic (ROEMIN W2) Improved Growth Performance and Intestinal Histomorphological Structure in Broilers Challenged With E.Coli". ARJA Volume 2; pp:1-12

Copyright (C) 2016 El-Hamamy M.M, Amina A. Dessouki, Rania.Hamad, Manal M. A. Mahmoud, This is an open access article distributed under the Creative Commons Attribution License, which permits unrestricted use, distribution, and reproduction in any medium, provided the original work is properly cited. 